\title{
Tell communities and wetlands in Neolithic Pelagonia, Republic of Macedonia
}

\author{
Goce Naumov \\ Center for Prehistoric Research, Museum of Macedonia, Skopje, MK \\ gocenaumov@gmail.com
}

\begin{abstract}
Pelagonia is the biggest valley in the Republic of Macedonia, positioned in its mountainous southwestern area. It was first inhabited around 6000 BC by agricultural societies, which established the tell settlements in the region. Their villages were densely concentrated in several regional centres located near wetlands and rivers. These farming communities produced a variety of ceramic household items with pronounced features of a distinct identity, such as white painted pottery, anthropomorphic house models, figurines, tablets and stamps. The particular landscape and isolated network of Early Neolithic tell societies in Pelagonia remained unaffected until the Late Neolithic, which was an outcome of the idiosyncratic and strong relationship between the environment, dwellings and human body. Therefore, the paper discusses the first farming communities in Pelagonia, as well as the process of how identity was manifested in regard to the wetland environment and networks.

IZVLEČEK - Pelagonija je največja dolina v Republiki Makedoniji in leži v jugozahodnem goratem predelu. Poljedelske skupnosti so regijo prvotno poselile dolino ok. 6000 pr. n. št. in postavile t. i. tell naselbine. Njihove vasi so bile zgoščene v številnih regionalnih centrih, ki so bili omejeni predvsem na območja močvirij in rek. Te poljedelske skupnosti so izdelovale različne keramične hišne izdelke z izrazitimi značilnostmi, ki kažejo posebne identitete kot so belo slikana lončenina, antropomorfni hišni modeli, figurine, plošče in žetoni. Značilna pokrajina in izolirana mreža povezav zgodnje neolitskih tell naselbin v Pelagoniji so ostale nespremenjene do poznega neolitika, kar je rezultat značilne in močne povezave med okoljem, naselbinami in človeškim telesom. V članku se zato ukvarjamo tako s pojavom prvih poljedelskih skupnosti v Pelagoniji kot tudi z načinom, kako se je glede na vlažno okolje in mreže povezav oblikovala njihova identiteta.
\end{abstract}

KEY WORDS - Pelagonia; Neolithic; wetlands; networks; chronology

\section{Introduction}

The Balkans played a significant role in the introduction of agriculture and new ways of life in Europe. This process started in the middle of $7^{\text {th }}$ millennium and continuously modified a large number of societies and landscapes on the continent. In this dynamic prehistoric environment, a particular group of communities inhabiting a valley in Pelagonia significantly contributed to the integration of new economic, social and symbolic practices (Fig. 1). The elongated valley, oriented north-south, lies in the Republic of Macedonia and Greece, incorporating the towns of Prilep, Bitola and Florina. Since prehistory, this basin has provided solid subsistence and so it has been continuously settled until the present. The fertile alluvial soil near wetlands was the major feature that prompted numerous communities in the Neolithic to build the first dwellings on the artificial mounds they created. The calibrated dates based on radiocarbon analysis from the 1970 s indicate that the region was occupied around the beginning of the $6^{\text {th }}$ millennium $\mathrm{BC}$, although some dates with high standard deviation reach back to the middle of the 7th millennium (Srdoc et al. 1977; $\mathrm{Va}$ lastro et al. 1977; Naumov 2016a). New AMS radiocarbon analysis will determine the precise dates of earliest sites, but nevertheless the process of Neoli- 
thisation was synchronous with that in the neighboring regions. The large scale excavations in the 1970s supports this argument, as numerous finds are similar to those unearthed in the Korçë basin (Albania) and Amindeon area (Greece).

Interest in the prehistory of Pelagonia started during the First World War, when several Paleolithic sites were researched (Malez 1979; Kuzman 1995). Thereafter, some campaigns by different teams commenced, including those of American institutions directed by Vladimir Fewkes and by British archaeologists guided by Walter A. Heurtley (Fewkes et al. 1933; Heurtley 1939; Galovic 1964). These were

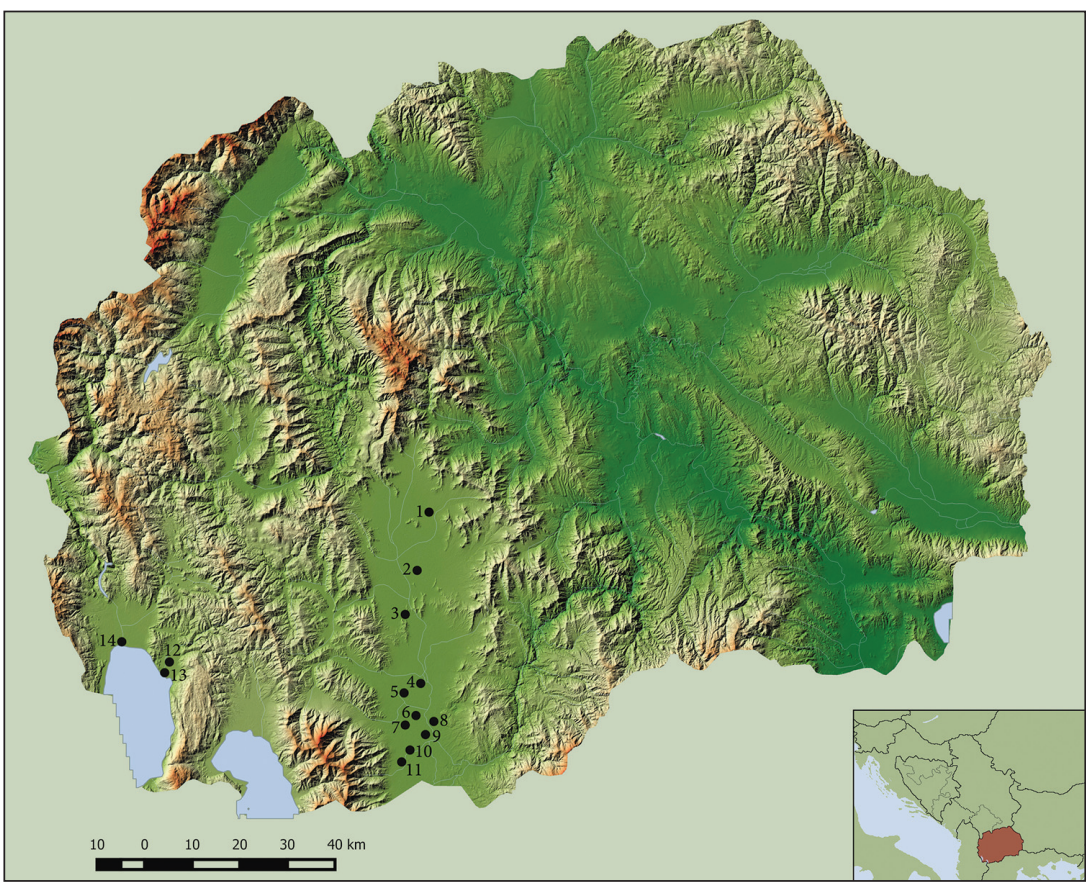

Fig. 1. Map of the Republic of Macedonia with location of sites discussed in paper. Pelagonia: 1 Senokos; 2 Slavej; 3 Topolčani; 4 Radobor; 5 Mogila; 6 Trn; 7 Karamani; 8 Dobromiri; 9 Optičari; 10 Porodin; 11 Veluška Tumba. Lake Ohrid: 12 Dolno Trnovo; 13 Ohridati; 14 Ustie na Drim. smaller-scale excavations and mainly prospections which recorded the first Neolithic sites and indicated the character of settlements as tells. It was a significant step forward in introducing Pelagonia as a region where numerous communities established villages in the Early Neolithic and chose the wetland area as an integral part of their lives. Furthermore, the interest in the Neolithic of Pelagonia increased after the Second World War, when more thorough excavations were performed, but an apparent boost in research was initiated in 1970s, when a number of excavations were executed on sites at Porodin, Mogila, Dobromiri, Karamani, Radobor, Trn and Topolčani (Simoska, Sanev 1976; Todorović et al. 1987; Sanev 1995; Naumov 2009a).

These campaigns provided most of the data which even today is the main source for understanding Neolithic societies living on this valley. After the research boom in the 1970s, archaeological interest in Pelagonia suddenly decreased, with the exception of excavations at Vrbjani and Optičari in the 1980s ( $K i$ tanoski et al. 1990; Simoska, Kuzman 1990). Nearly three decades passed without any thorough research in this region, until the 2000s, when excavations at Senokos, Mogila, and Vrbjani began, as well as geophysical scanning, GIS mapping, the calibration of chronology and archaeobotanical research of Neolithic tells in Pelagonia (Temelkoski, Mitkoski 2006; Nau-

mov et al. 2014; Naumov, Stojkoski 2015; Naumov, Tomaž 2015; Naumov et al. in print). Although still modest, the current data obtained from the research in 1970's and that of the last decade, provide elementary information on Neolithic communities, their dwellings, material culture and environment. There is still much to be done for a thorough understanding of the social setting and interaction with nature in Neolithic Pelagonia, but the available data allow for the initial reconstruction of the landscape and settlements and how they were integrated in the wetland environment.

\section{The geography of wetlands}

Pelagonia is an elongated valley in the geographic region of Macedonia, in Southeast Europe. The valley is nearly $5000 \mathrm{~m}^{2}$ in area, with a length of approx. $80 \mathrm{~km}$ and width of $35 \mathrm{~km}$. Geologically, it dates to the Pelagonia horst anticlinorum and consists of a neotectonic basin structure initiated in the Middle Miocene (Arsovski 1997; Dumurdzanov et al. 2004). The wider region is built from Precambrian and $\mathrm{Pa}$ leozoic metamorphic rocks developed by the peripheral mountains surrounding Neogene lake sediments. To the North is Mt Dautica, eastward are Babuna and Selečka, southernmost are Nidje and Neredska, while to the west are Baba, Plakenska, and Buševa (Trifunovski 1998). The valley is formed on 
Neogene lake sediments including saline sandstones, clean siltstone, clay, sandy clay, and gravel (Fig. 2). Quaternary lake sediments consist of coarse sandy gravel fraction and marshy sediments, proluvial and diluvial deposits from roughly clastic sediment of silty-clay, sands and gravels (Mirčovski et al. 2015). The graben itself is developed on Precambrian gneiss and schist and Paleozoic schist and granite of the Pelagonian tectonic unit. This unit was formed in the Late Miocene and contained lacustrine environment from the Late Miocene until the end of the Pliocene and Pleistocene. The Miocene-Pliocene section is covered by $5-15 \mathrm{~m}$ of Pleistocene alluvial-proluvial sediments (Dumurdzanov et al. 2004).

The environment deposited a thick layer of alluvial and Neogene lake sediments which affected the quality and fertility of the soil (Puteska et al. 2015). This was one of the primary motives for the dynamic inhabitation of Pelagonia since the Early Neolithic and its continued exploitation. Also, the abundance of

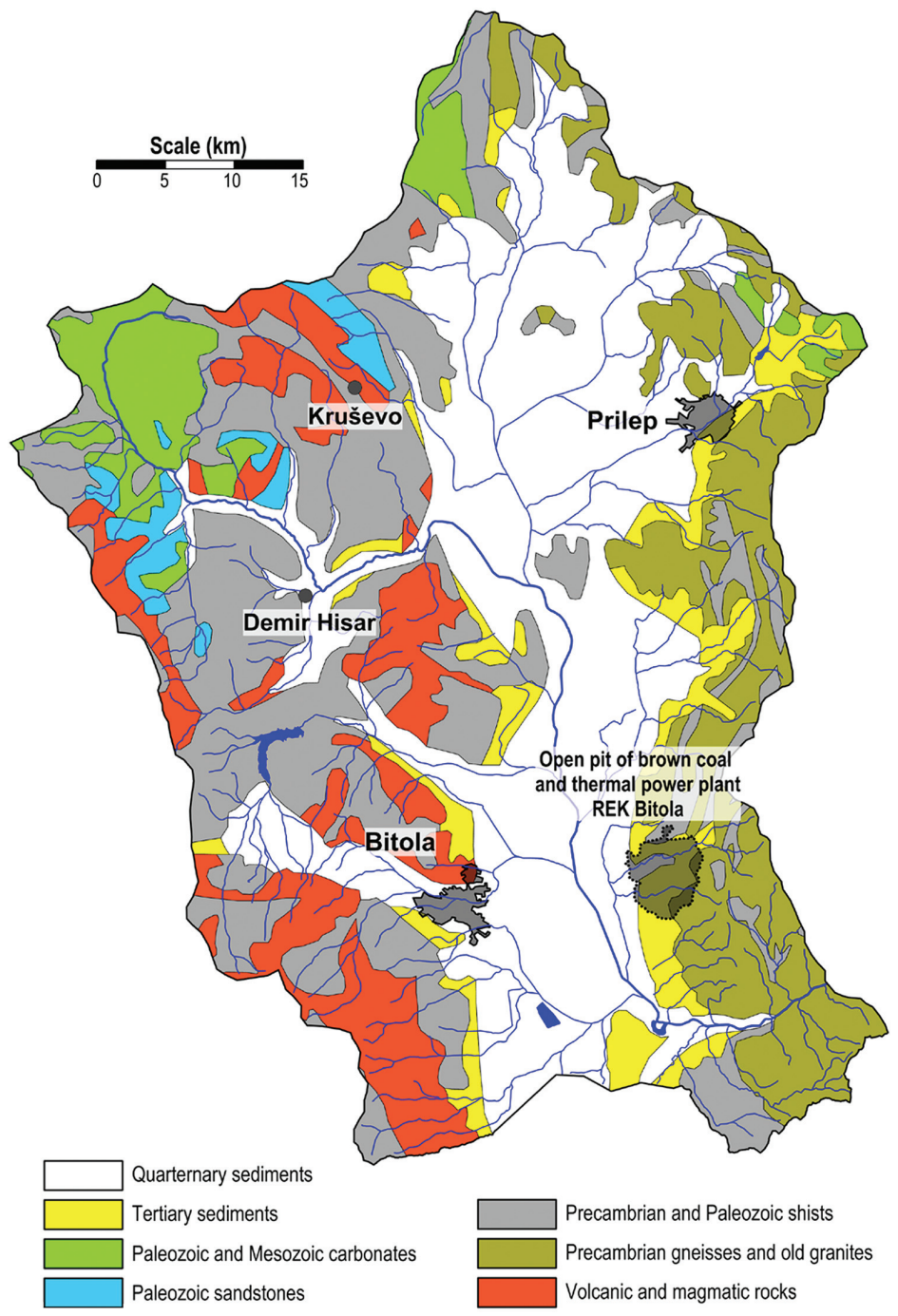

Fig. 2. Geological map of Pelagonia (Puteska et al. 2015.Fig. 2). underground waters and rivers contributed to soil fertility. The Crna Reka River is one of the biggest in the region and is used as a main waters ource in the agriculture. The Crna Reka's branches, such as the Dragor, Šemnica, and Eleška rivers, also contribute to irrigation. Hydrogeological complexes distributed swampy sediments (Mirčovski et al. 2015), and the flooding of rivers and appearance of underground waters caused by melting snow creates large areas of wetlands. In the period of heavy rains or snow melting, the rivers overflow their banks and in combination with underground waters create several smaller marshy lakes which were used throughout the year for fishing, hunting birds and providing resources for house building and weaving. These marshy lakes were intentionally and systematically dranied in the early 1960s, but were often exploited for subsistence economy, communication and boating (Trifunovski 1998). The recent floods confirmed that the marshes are again being created in the particular areas where swampy lakes existed before being drained, which indicates that their surroundings were preferred even in the Neolithic (Naumov, Stojkoski 2015).

Without new hydrogeological research in Pelagonia, it is hard to specify the environment at the end of $7^{\text {th }}$ millennium BC. Although it could be expected that the landscape did not significantly change in the last 10000 years, sampling is still necessary in order to understand thoroughly the climate and processes concerning waters and sediments in the central alluvial plain. Geographical maps from the end of $19^{\text {th }}$ and first half of $20^{\text {th }}$ century indicate that there were several isolated areas with marshes which were the same size or perhaps bigger in prehistory. Medieval sources even indicate that there was a smaller lake in Pelagonia and an island near the site known as Staroselo and Katarsko (Chausidis 2003). The frequent floods and dynamic underground waters probably affected the quantity and extent of the wetlands which were changing in various eras until their final drainage in the 1960s. The climate had an important role, as the one in Pelagonia is considered as modified continental and moderate continental, with hot, dry summers and cold, wet winters. Wide temperature fluctuations are frequent with a 
maximum of $40^{\circ} \mathrm{C}$ and minimum $-30^{\circ} \mathrm{C}$ in summer and winter, respectively. Annual precipitation is approx. $915 \mathrm{~mm}$, which, along with river floods, allow constant watering of the soil and the cultivation of cereals (Puteska et al. 2015).

Nevertheless, archaeological research in the 1970s asserts that Pelagonia in the Neolithic was mainly wetland area and therefore later inhabited by the first agricultural communities (Kitanoski et al. 1980; Naumov 2009a). This is also indicated by the calibrated dates of several sites in Pelagonia, which are somewhat later than those from Neolithic settlements in Ovče Pole, a region north-east of Pelagonia (Naumov 2015a; 2016a). In spite of recent chronological and hydrogeological results, archaeological excavations confirm large number of sites in this wetland area next to the Crna Reka and marshes ( $\mathrm{Si}$ moska, Sanev 1970). The fertile fields attracted larger groups of communities to establish settlements near wetlands, which is also supported by similar radiocarbon dates from several Neolithic villages (Fig. 3). This process began around $6000 \mathrm{BC}$, but continued throughout the entire millennium, with a number of tell sites appearing and vanishing after several centuries of intensive occupation.

\section{Chronology of tells}

The date of the establishment of tells is still under debate as the proposals are based mainly on relative chronology, i.e. on comparison of material culture (Sanev 1995). There were few dates from radiocarbon analysis of samples unearthed at sites in Pelagonia, but they were not used in Macedonian archaeology. They have recently been incorporated into the research of tells in this region and provided an entirely new perspective on the initial stages of the Neolithic and its progress in the $6^{\text {th }}$ millennium BC (Naumov 2009a; 2015a; Naumov in print). Several tells in Pelagonia were dated in the 1970s in two laboratories at the Ruđer Bošković Institute in Zagreb and the University of Texas in Austin (Srdoć et al. 1977; Valastro et al. 1977). Although this was a few decades ago, they remain the only reference for the prehistoric chronology of Pelagonia. There are high standard deviations among the provided dates, but some could be used as a reference for a chronological framework.

The earliest date so far is from Topolčani, which dates to the middle of the $7^{\text {th }}$ millennium (Fig. 3). This quite early date is under discussion due to sev-

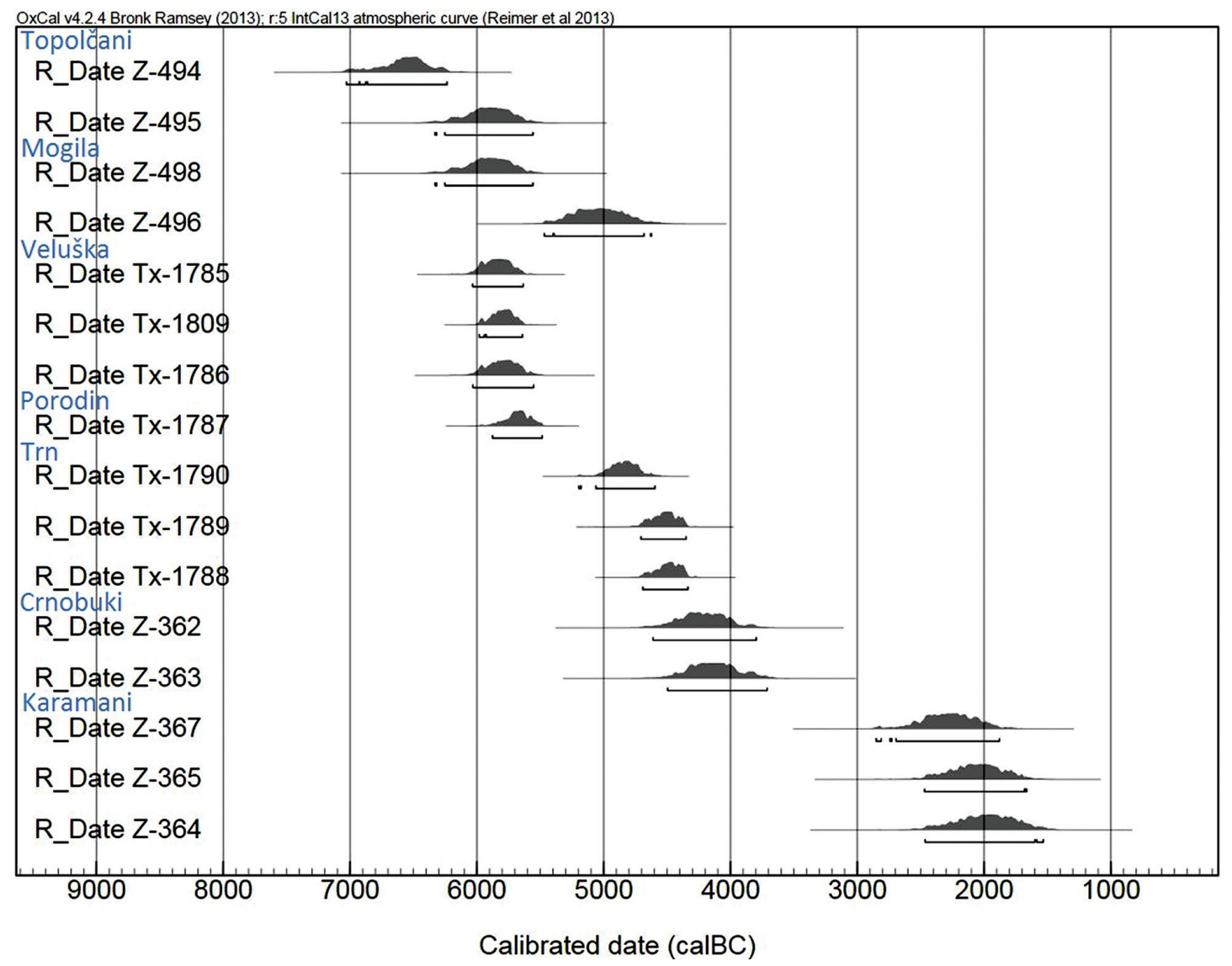

Fig. 3. Calibrated radiocarbon dates from tell sites in Pelagonia (after Naumov 2016a.Fig. 10). 
eral problems. First, there is high standard deviation in the result, which currently is not considered in archeological research as adequate information. Also, the sample could come from organic material which is much older than the period of its use at the Neolithic settlement at Topolčani. But if some dates from northern parts of Greece and Central Albania are considered, then such early date is not uncommon for the Balkans (Reingruber 2011; Karamitrou Mentessidi et al. 2013; Bunguri 2014), and they are sometimes associated with the first farming pioneers exploring and later settling this peninsula (Perlès 2001). The second date from Topolčani corresponds more with the chronology of other tells in Pelagonia, although with a high standard deviation in the result, which is much later and could be set at the very beginning of the $6^{\text {th }}$ millennium $\mathrm{BC}$.

Several dates from Mogila, Veluška Tumba, and Porodin are close to this one from Topolčani, and therefore could be proposed as more referential for the initial Neolithic stages of tell sites in Pelagonian wetlands. New dating and detailed chronological sequences are required in order to propose more complete dates for Pelagonia, although currently this should be considered as the only precise reference 1 . In regard to the very end of the Neolithic period in Pelagonia, the tell at Trn provides several dates from the first half of the $5^{\text {th }}$ millenium BC. Both dates and material culture are common for the Late Neolithic in the Balkans and therefore could be proposed as the current chronological reference for the last Neolithic stage in Pelagonia (Simoska, Sanev 1977; Naumov 2016a; in print). This temporal range indicates that Neolithic tells appeared and were abondoned over a period of approx. two millennia. Some of these settlements were occupied for only a few centuries, while others were reused in later periods (Chalcolithic and Bronze Age) and even as an area for Roman villas rusticas in the Classical Period or necropolises in the Middle Ages.

\section{Settlements in wetlands}

The first Neolithic villages were established according to the environment and natural conditions. Wetlands and the surrounding fields were chosen as fertile ground able to provide a subsistence economy. Although paleoecological research has not been undertaken for Neolithic Pelagonia, a survey from the neighboring regions indicates progressive refore- station after the Pleistocene and a densely forested landscape with oak, pine, elm, hazel, etc. (Demoule, Perlès 1993). Both the alluvial plain and hills around it were preferred locations for Early Neolithic settlements, but the highest number of villages has been recorded in the flatlands (Simoska, Sanev 1970). The majority were close to marshes due to the wellwatered soil and proximity of resources for food, building, plaiting and basketry. Recently, the marshes were considered as source of a malaria, but current research shows that particular communities developed cultural, dietary and behaviour adaptations and reduced the risk of death (Sabattani et al. 2010). Therefore, the Pelagonian wetlands could be considered an ideal landscape for siting some of the first agricultural villages in the region.

Most of the settlements are tell sites, although some sites are positioned on the hills near the valley. Considering that most of the valley is flatland, it was necessary to establish artificial mounds close to marshes. The first agricultural communities in Pelagonia used small natural humps on which they constructed wattle and daub houses (Simoska, Sanev 1976; Kitanoski et al. 1990; Tolevski 2009; Naumov et al. in print). Tells were dispersed all over the valley, but the majority around the marshy lakes (Fig. 4). Recent research indicates that Neolithic societies in Pelagonia used the principal water resources, so that many of them are close to marshes and along the Crna Reka. Although the total current number of documented tells in Pelagonia is more than 120 , in its central part alone 93 sites have been recorded, most of which are tells (Naumov, Stojko$s k i$ 2015). There are major bigger tells all over the valley, with a number of smaller tells established in their vicinity. Until thorough excavations and further dating, it remains open as to whether these clusters of tells were synchronous and related to each other. In some areas there are groups of 3 to 8 tells, which indicates several scenarios: 1) they could have been established in different periods, although pottery at some neighboring sites is quite similar; 2) a single tell could be the area's centre, while a few others could be peripheral, consisting of communities not incorporated within the centre or belonging to a group of newcomers willing to be integrated into the society (Naumov, Stojkoski 2015). Nevertheless, such a high density of tells in a particular area indicates more complex social processes in the Neolithic and a division of both status and space.

1 Few months ago ${ }^{14} \mathrm{C}$ analysis on seeds unearthed from tells at Porodin and Optičari was done at The University of Bern. These still unpublished dates indicate that the initial occupation of the sites was at the very beginning of $6^{\text {th }}$ millennium $\mathrm{BC}$ and partially correspond with the dates from 1970 s. 
In regard to the division of space, geophysical scanning at a few tells shows practices common to wellorganised societies. At the tell at Dobromiri, a number of dwellings are disposed in lines, while the centre consists of constructions organised around an empty circular area (Fig. 5a). The entire village is enclosed with a ditch and a few entrances apparently divided the tell from its surroundings (Naumov et al. 2014). This ditch could be to protect the inhabitants from attack, from wild animals and fires, but it could also be a symbolic border between the domus and agrios, i.e. domesticated and wild world (Hodder 1990; Bradley 2005; Harding et al. 2006). In spite of this, at other sites the geophysical scanning does not show a similar division of space. The tell at Trn is later, has no ditch enclosing the village and has one massive building at its very centre (Fig. 5b). These differences could relate to dissimilar social practices or to diverse communities inhabiting sites divided only by the wide Crna Reka. That they belong to different chronological and cultural Neolithic levels could be a further explanation, although this does not always con-

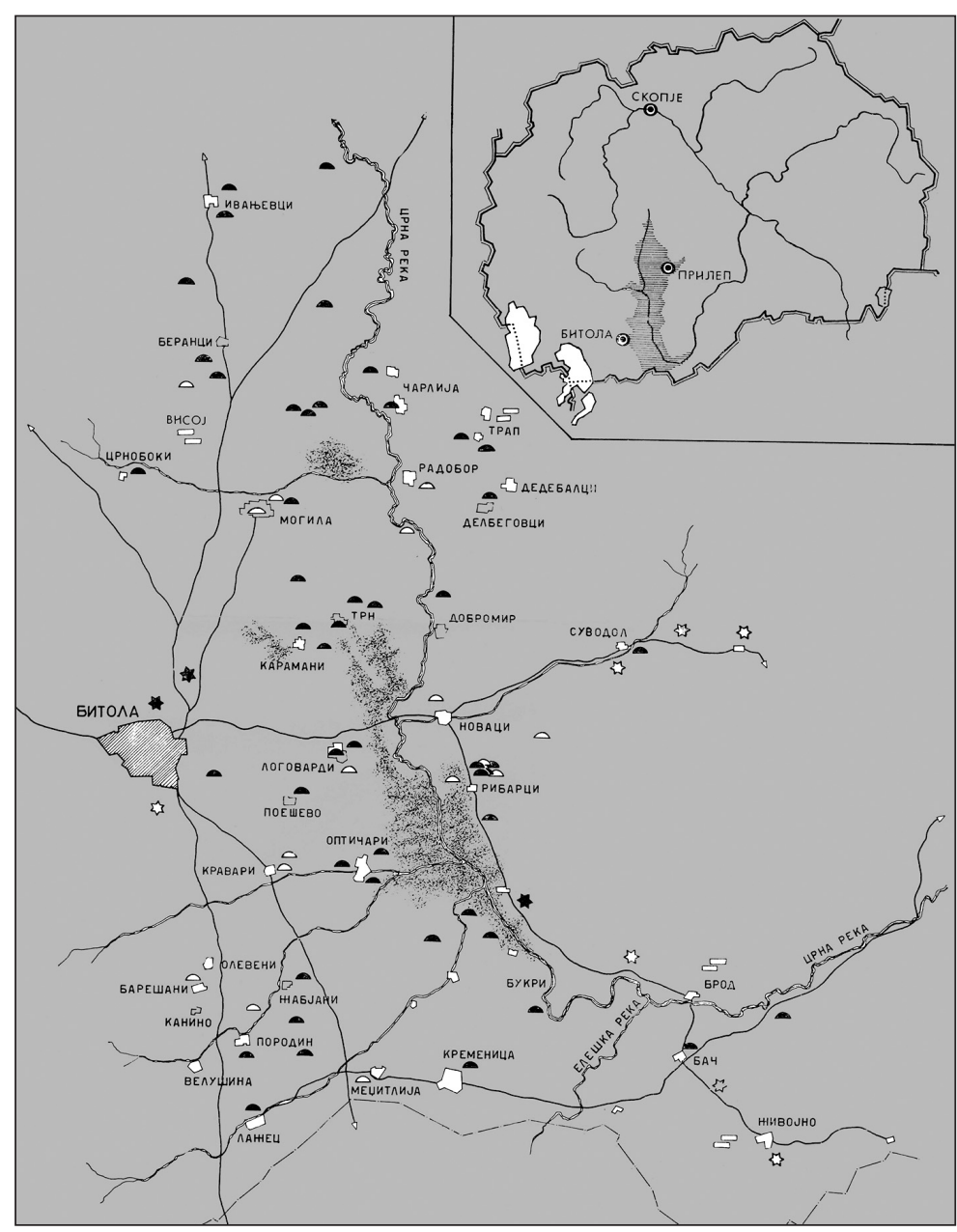

Fig. 4. Location of tell sites around wetlands in central Pelagonia (after Simoska, Sanev 1976.Map 1). sider diverse societies, but sometimes the absorption of new cultural features (Naumov et al. 2014).

The buildings in the Neolithic villages of Pelagonia are mainly unified, with only a few exceptions. Most of the architecture consists of rectangular dwellings made of wattle and daub, with posts and triangular roofs covered with straw (Tolevski 2009). The dwellings at Veluška Tumba and Tumba at Porodin have feature common to the Neolithic houses in the Balkans, while at many other sites no outlines of structures are confirmed (Grbić et al. 1960; Simoska, Sanev 1975). The dwelling at Slavej has the same plan (Fig. 6), but differs from the others in having an enormous elongated structure consisting of one main large container and four smaller disposed laterally (Mitkoski 2005). There are different explanations of this structure, with some stressing cultic aspects and others focusing on its economic features symbolically intensified by the applied patterns on the walls ( $K i$ tanoski et al. 1990; Mitkoski, Naumov 2007). Recent excavations at the same site indicate another dwelling in the vicinity of this one. The concentration of many structures within one dwelling for processing cereals (platforms, ovens, fire places, grind stones, grinders, etc.) indicates an area with intensive economic dynamism (Naumov et al. in print). Considering these two large buildings in the central part of the tell it could be proposed that a huge quantity of wheatflour and bread was produced there. They could be communal buildings for the public provision of bread, which has already been proposed for some other sites in the Balkans (Budja 2003).

The pit houses at the Pešterica and Senokos sites, with banches and platforms in their interior, are exceptions to common Neolithic architectural traditions (Kitanoski et al. 1980; Temelkoski, Mitkoski 2006). A specific structure is confirmed on a tell at Mogila, where a building with a dense concentration of posts but without the remains of daub in its vicinity was recorded (Naumov, Tomaž 2015). This structure is on the very periphery of the tell, which indicates the building of pile dwellings in Pelagonia 
Fig. 5. Geomagnetic maps from geophy sical scanning of tells at Dobromiri (a) and Trn (b) (after Naumov et al. 2013. Fig. 11-12).

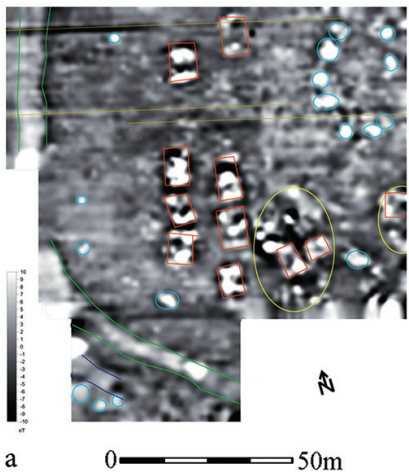

due to the presence of water beside and below the site. The building of structures on posts was a common practice in Pelagonian villages even in the $20^{\text {th }}$ century. Many were used for economic purposes in order to protect food resources from waterlogged ground and were sometimes used as huts for fishing, seasonal work or ritual purposes (Chausidis 2009).

With regard to pile dwellings or structures on wooden posts, house models should be an indication of the presence of such buildings in Pelagonia. House models are a common feature of the Balkan Neolithic, and there are several variations in shape ( $\mathrm{Ni}$ kolov 2007). Those in Pelagonia have particluar features which accentuate architectonic details, and have so-called 'legs' on the bottom (Naumov 2011). The study of house models has mainly focused on their symbolic aspects (Temelkoski, Mitkoski 2005; Chausidis 2009; Naumov 2011), but the social and architectonic features have also been considered (Tolevski 2009; Naumov 2013). The majority have 'legs', without a hearth or oven in the interior, and could be stylised representations of pile dwellings or buildings used to store cereals, vegetables, meat, etc.

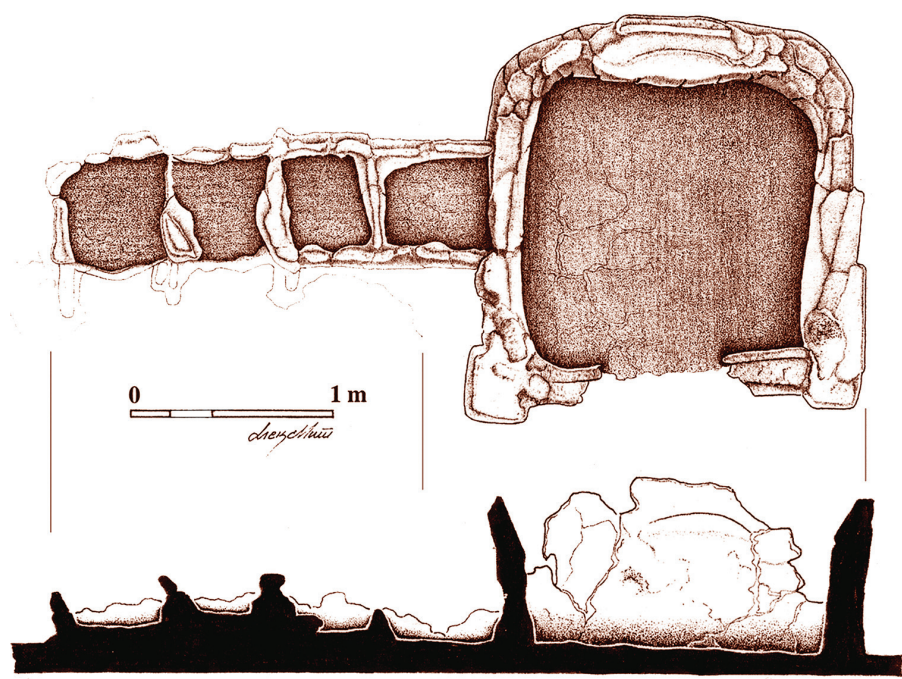

Fig. 6. Large clay structure (granary) inside a Neolithic house in 'Vrbjanska Čuka' at Slavej (after Mitkoski 2005.P1. 1).

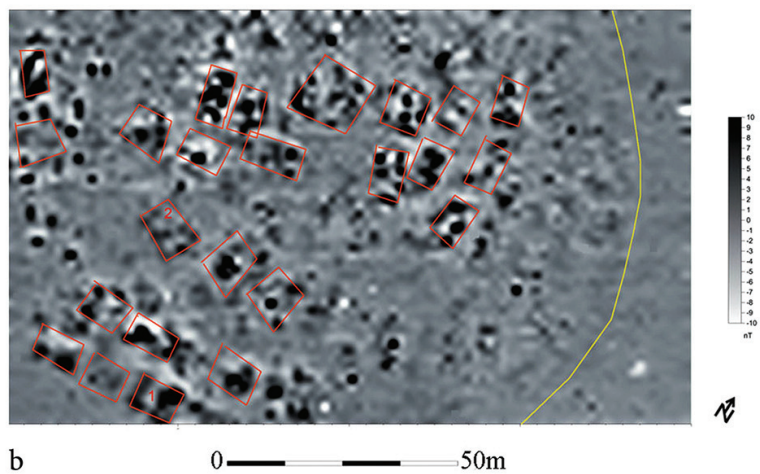

(Fig. $7 \mathrm{a}, \mathrm{c}$ ). The model found at Porodin has a broken bottom and a house interior, so it could be interpreted as a wattle and daub ground-level dwelling. But recent finds at Lemnochri II in the Amindeon basin (Greece) confirm the wider production of almost identical models which are thought to be representations of two storey houses (Chrysostomou et al. 2015). Such houses have not been documented in Pelagonia so far, but given the proximity and similar environment of these regions, similar buildings could be expected in Pelagonia as well.

\section{Material culture}

The house models produced at Neolithic sites in Pelagonia are an appropriate introduction to the material culture of the societies living in the wetlands of this region. Regarding the amount of house models and its architectonic details, Pelagonia is one of the rare regions in the Balkans with such a focus on house representations. It indicates that the communities producing these models were focused on the social and symbolic significance of the house and its importance within Neolithic life (Naumov 2013). An emphasis on the house throughout material culture was related to the stylised portrayal of dwellings, but also integrated these miniature rerpesentations of buildings into more complex symbolic realm. Besides their specific visual features, associated with variety of semiotic atributes, the models also have a shallow container not designed to store a large amount of material. There have been different observations on how and why this part was used, but archeologists are mainly united on the ritual function that these models could have had (Temelkoski, Mitkoski 2005; Nikolov 2007; Chausidis 2009; Naumov 2011). The remains of fire suggests that something was burnt in their interior, although further chemical analysis could trace the ma- 
terials which were used in these practices. The deposition of figurines, stones and organic materials (flour, vegetation, liquids, etc.) should certainly not be excluded as composite parts of symbolic activities associated with these artefacts in the Neolithic.

The symbolism within the house models was not only applied to their ritual use, but also to the more complex semiotic identification of the house and the human body. From the last stages of the Early Neolithic in Pelagonia anthropomorphic house models were produced (Simoska, Sanev 1976; Sanev 2006; Chausidis 2007). They comprise a cylinder with a representation of a human face and house model instead of the lower half of the human body (Fig. 7b). Although similar artefacts were produced in neghbouring regions north and north-east of Pelagonia, those particular to this region have apparent features of dwellings, in spite of others which consisted of a box instead of a house model. Such apparent identification of humans with houses is not common in the wider region, so discussions raised the question of who or what was manifested through these artefacts. Alhough they were speculatively interpreted as 'Great Mothers' (Sanev 1988; Zdravkovski 2006a), still more thorough observation indicates that they probably represented the individuals associated with the house, such as the family head (paterfamilias), an ancestor, deceased person, distinguished individual, etc. (Naumov 2013). Nevertheless, the anthropomorphic house models attest to the symbolic relationship with communities and their dwellings, which was particularly emphasised among the Neolithic villages within the wetlands of Pelagonia. It is in accord to Hodder's concept of domus and the accentuation of the domestic sphere in the Neolithic (Hodder 1990), but also emphasises the idea of the domestication of human body as a process synchronous with the domestication of animals and cultivation of plants.

The prominence of symbolic features of the human body in Pelagonia was not only manifested in this hybrid relationship between man and house, but also in the production of figurines. The figurines were miniature representations of bodies, and stressed particular segments of corporeality and embodiment (Joyce 2000; Lesure 2011). In spite of other regions where sexless figurines prevail, in Pelagonia most of the figurines are female, with an apparent focus on the buttocks and genital area (Fig. 8). Corporeality employed body gestures which often includes hands on the abdomen or genitalia and also covering of genitalia with particular round applications (Naumov 2014). Animal figurines were also found in Pelagonia, but in significantly smaller numbers compared to human representations (Temelkoski, Mitkoski 2001; Vasileva 2005). The interpretation of figurines ranges from individuals to deities (Gimbutas 1989; Bailey 2005), but although their meaning is hard to grasp, it is indicative that they were intended to represent features of a human body. The characteristics that were represented bear the apparent features of humans and thus reflect regional identity and the understanding of embodiment in that particular region.

In terms of regional identity, pottery is one of the most distinguished representatives. Not only typology, but patterns painted, applied, and incised on the vessels are indicators of regional preferences in pottery production (Fig. 9). Along with the first extensive excavation of Neolithic tells in Pelagonia, pottery was regarded as a cultural and chronological marker. Thus, the types of vessel and their decoration were primarily determinants for the archaeological culture identified with Pelagonia (i.e. the Velušina-Porodin group) and consequently the reference for each Neolithic phase (Simoska, Sanev 1976; Garašanin 1979). Particular shapes and patterns were associated with the Early, Middle or Late Neolithic, although further analysis demonstrate that such an archaeological division of decoration is not always accurate and was thus modified (Sanev 1995; Naumov 2009b; 2015a). Nevertheless, besides its chronological, economic and technological engagement pottery also has complex social features. 
The majority of Early Neolithic white painted patterns or Late Neolithic incrustations were not only an aesthetic expression of communities inhabiting Pelagonia, but also markers of their identity. Most of the patterns on vessels were common mainly in Pelagonia, but not in the surrounding regions. This indicates that as a geographically encircled area, Pelagonia was inhabited by communities which developed a distinct identity mainly manifested in pottery, but also in other elements of material culture (Naumov 2010), which includes figurines, models, stamps, and tools, which besides their general characteristis also have authentic features unique to this region. Nevertheless, although geographically isolated, the communities in Pelagonia established dynamic networks mainly with those to the southwest, while northerly regions were apparently omitted. A number of painted vessels, anthropomorphic house models, 'altars' and stamps found at Neolithic sites in the Lake Ohrid basin are almost identical to their counterparts in Pelagonia (Kuzman et al. 1989; Kuzman 2013; Naumov 2016b). Although geographical obstacles were not prominent between these two regions, networks were intensified in the Early and Late Neolithic, despite less intensive interaction with other northern areas (Naumov in print).

Tools comprise the final group of material culture incorporated in this review of Pelagonian wetlands in the Neolithic, although more objects should be included in an extensive review. Regarding regional specifications, ceramic projectiles should be mentioned, as they are absent or rare in neighbouring regions (Grbić et al. 1960; Mitkoski 2005). They are found in large numbers at Pelagonian sites, which suggests they were more frequently used in hunting and fighting than for other purposes. Arrowheads are almost absent, thus confirming the preference for clay sling missiles for both hunting and fighting. Also their use in stockbreeding and controlling pasturing flocks or herds has been proposed (Perlès 2001), and the accuracy of sunbaked projectiles in combat has also been em- b
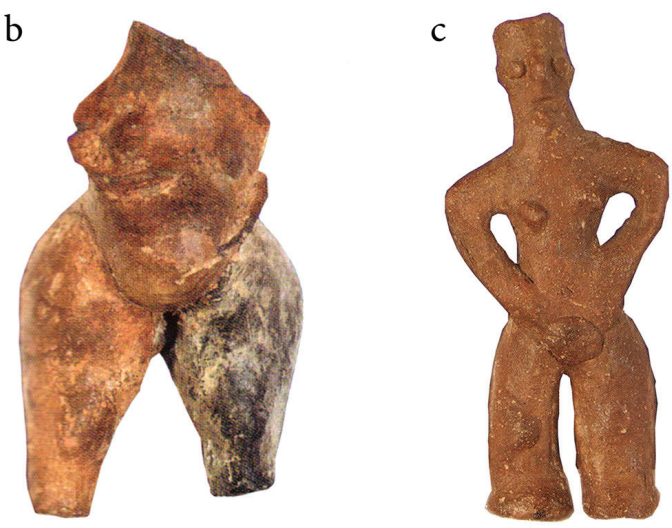

Fig. 8. Neolithic anthropomorphic figurines from 'Tumba' and 'Veluška Tumba' at Porodin: a height $7 \mathrm{~cm}$ (Kolištrkoska Nasteva 2005. Fig. 7); b height 12cm (Kolištrkoska Nasteva 2005.Fig. 26); c height 6cm (Kolištrkoska Nasteva 2005.Fig. 5).

phasised (Runnels et al. 2009). In contrast to arrowheads, flint blades are more frequent and vary in shape and function, as well as a number of polished axes (Simoska, Sanev 1975; 1977; Kitanoski 1977; Simoska, Kuzman 1990; Kitanoski 1989; Naumov, Tomaž 2015; Naumov et al. in print). Bone tools are also very rare, perhaps because of the excavation methodology or chemical features of soil, as animal bones from the Neolithic are rarely present or reported. Ornaments are not within the scope of tools and are more concerned with decoration and identity. Bracelets and necklaces of stone, bone or shell are almost absent at Pelagonian sites, but their presence on human representations such as figurines and anthropomorphic house models indicate they were composite parts of an emphasised individual or communal identity (Naumov 2015b).

\section{Wetlands and networks}

Due to the vast bodies of water, wetlands were considered as areas consisting of unrefined and conservative societies incapable of producing a sophisticated material culture or establishing more complex spatial organisation within settlements and land-

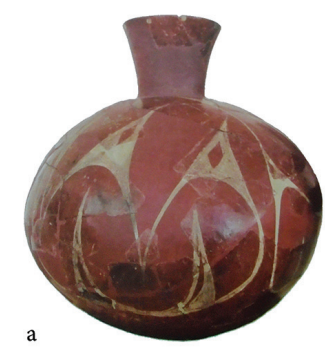

Fig. 9. Neolithic pottery from 'Tumba' and 'Veluška Tumba' at Porodin: a height 48cm (Fidanoski 2009.Pl. 66/7); b width $23 \mathrm{~cm}$ (Fidanoski 2009.Pl. 66/5); c height $17 \mathrm{~cm}$ (Fidanoski 2009.PI. 67/3). 
scapes. But more thorough research on excavated finds and contexts, as well as the integration of science and theory within wetland archaeology, has provided a new understanding of these areas and the communities living there (Van de Noort, O'Sullivan 2006). The first agriculturists in the wetlands of Pelagonia are a remarkable illustration of how societies inhabiting such areas were far from unrefined or unskilled at crafts. The brief overview of material culture presented above indicates that the Neolithic wetlanders in Pelagonia and in many other similar areas of the Balkans were exceptional manufacturers, rational exploiters and meticulous organisers of living space. Moreover, they engaged their cognition in a sophisticted way in order to incorporate hybridism and embodiment within material culture or to geometrically organise the scrupulous white painted patterns on the curved surfaces of vessels. Although this blossoming of art, symbolic visualisation and patterning of space appear as a kind of sudden 'explosion' in Pelagonia, it was gradually integrated in a long-term process developed by many generations in diverse regions.

The wetlands in the valley within the encircled landscape of mountains in Pelagonia were even more of a challenge to newly arrived farmers or to the indigenous population that rapidly absorbed Neolithic ways of life. Constant access to fertile fields, confrontation with floods and isolation from other regions by high mountains enabled a solid focus on local identity and particularly a genuine understanding of the human body and the landscape. Therefore, the spatial organisation of tells around marshy lakes, the conception of corporeal hybridism or incorporation of geometry within pottery decoration were advanced as achievements not similar to, or at least modified, further north of Pelagonia. The material culture associated with these principles was exceptional, made with a high level of expertise and quality and attractive to communities in neighbouring regions.

Although developed within an area enclosed by mountains, Pelagonian societies were not preserved in regional isolation. Its aesthetic and symbolic features reached other farming communities in the vicinity. Some of them absorbed or exchanged only parts of this Pelagonian 'culture', while others were established thorough networks. In terms of material culture, Pelagonian societies were more southerly oriented, and did not favour strong relationships with those to the north or east. The painted patterns of vessels, figurines' features, model houses and an- thropomorphic cylinders significantly differ from what was produced by the so-called AmzabegovoVršnik, Starčevo, and Karanovo cultures (Garašanin 1979; Todorova, Vaisov 1993; Sanev 1994). There are surely glimpses of Pelagonian artefacts in regions defined by these 'cultures', as witnessed by the anthropomorphic lanterns, figurines and the few painted patterns in the Skopje and Ovče Pole region (Naumov 2010). More evident elements of the Pelagonian Neolithic are present in the very close region of Raec across Mt Babuna and in the Polog valley northwest of Pelagonia (Sinadinovski 2016; Zdravkovski 2006b). The similarities are mainly in the white painted patterns on vessels from the Middle Neolithic levels of a few sites in Pelagonia. Therefore, it can be proposed that contacts were firmly established later, although communication between these regions in the Early Neolithic should not be excluded.

The solid networks of Pelagonia with other areas are most apparent in the Lake Ohrid basin. From the Early Neolithic, settlements produced white painted pottery, anthropomorphic model houses and 'altars' almost identical to those in Pelagonia (Naumov 2016b; in print). This is evidenced at Dolno Trnovo, which is on the alluvial plain close to the lake (Kuzman et al. 1989). Some painted patterns are also present in Korçë basin in Albania, but anthropomorphic house models are entirely absent there (Ruzi 2009; Bunguri 2014). Intriguingly, the Pelagonian features are not so apparent or present at Neolithic sites south and south-east of this valley, like those in the Amindeon, Servia and Giannitsa regions in Greece, which are more like the pottery produced by communities in the Korçë basin and even in the 0vče Pole valley than in Pelagonia. Future research on Early Neolithic data could provide a model different from the one proposed, but current research and published material suggest the lack of a strong relationship with the south, in spite of firm networks with the south-west, i.e. Lake Ohrid basin.

The firm networks between Pelagonia and the Lake Ohrid basin were maintained in the Late Neolithic as well when an abrupt change in material culture appeared synchronically in both regions (Naumov in print). Black polished pottery with white incrustation and stamps with identical patterns have been unearthed at sites at Ohridati and Ustie na Drim (Kuzman 2009; 2013). In the Late Neolithic levels of Ohridati, an anthropomorphic cylinder was found that has apparent similarities with those previously produced in Pelagonia, but utterly absent in later pe- 
riods. This cylinder indicates that some Pelagonian elements were retained in the Lake Ohrid basin even when they were abandoned among communities in Pelagonia. Nevertheless, the recently published results of a dendrochronological analysis of piles in Ohridati provide Middle Neolithic dates around 5500 BC (Westphal et al. 2010). This indicates that some social processes were synchronous in these two regions, so some earlier features from Pelagonia do not have to be considered as Late Neolithic in the Lake Ohrid basin.

Regarding the apparent geometrical incrustations on pottery, it was previously suggested that such Late Neolithic novelties were introduced from Adriatic communities (Benac 1979; 1989; Sanev 1995), but recent research indicates that the same features on pottery were present quite early in Western Turkey and gradually transposed to the Balkans, including Pelagonia and the Ohrid area (Özdoğan 1993; 2011; Steadman 1995; Naumov 2016b). The networks between Ohrid and Pelagonia continued in later prehistoric periods as well, as witnessed by the similar pottery, jewelry, burial masks, weaponry, etc. (Mikulčić 1966; Mitrevski 1997). This connection was probably interrupted at the end of the Iron Age, when novel cultural features dominated and the ethnic reorganisation of territories became more dynamic.

Although these two regions were divided by high mountains - Baba, Galičica and Bigla - the Neolithic and later prehistoric communities inhabiting the separated valleys established and maintained solid contacts, economic exchange and a shared common identity. In spite of this, regions which were closer to Pelagonia and easier to approach were culturally more distant and material culture was not very similar to what was found in the Lake Ohrid region. Future research will provide new data for a more thorough understanding of the motives for having strong networks between these geographically divided regions and elaborate the integrated processes within social relationships and symbolic practices. Until then, it may be proposed that similar wetland environments and the proximity of a lake as resource and symbolic landscape were major reasons for intensive communication and shared identity manifested in pottery, models, 'altars' and stamps.

\section{Conclusion}

The particular focus on tell sites has attracted more attention in recent decades than hitherto. Although many tell sites have been partially excavated in
Southeast Europe, they have rarely been regarded as architectural and social entities (Kotsakis 1999; Perlès 1999; Rosenstock 2009; Hofmann et al. 2012). Recent research indicates that tell sites are complex settlements with highly intensified social and infrastructural dynamics, which is manifested in their outline, building patterns, material culture, rituals, etc. The Neolithic tells in Pelagonia have similar features and require further exploration in order to specify the dynamics within these specific agricultural settlements. They were excavated mainly in the 1970s, but a thorough understanding of their social, architectural, economic, and symbolic spheres was never extensively explored or proposed. Given their authenticity, they can provide a novel insight into the establishment and development of these specific settlements in the Balkans.

Most Pelagonian tells are located on alluvial flatlands, while the surrounding mountains slopes mainly consisted of flat settlements on hilly areas. This concentration of vast numbers of tells on flatlands was intentional rather precarious due to frequent flooding, therefore the first agricultural communities in this region have deliberately chose small bulky mounds made of Neogene lake sediments. These were the fundamental basis for the villages which gradually developed into tells. This bulky and sandy ground has been found to be the lowest level at many tells in Pelagonia where the first dwellings were established (Simoska, Sanev 1975; Simoska et al. 1979; Naumov, Tomaž 2015; Naumov et al. in print). In this way, the first Pelagonian farmers interacted with the wetland environment and evaded the rising underground water after heavy rains, flooding of the Crna Reka and snowmelt water from the surrounding high mountains. The forests on the mountain slopes provided plenty of wood for wattle and daub houses, but also for pile dwellings on the periphery of sites. Such constructions are recorded in Early Neolithic levels of the tell at Mogila, while a wooden post was unearthed from the Krušeanska Čuka tell (Naumov, Tomaž 2015; Todorović et al. 1987).

Regarding the successful management of settlements in various climatic conditions, the wetland environment in the valley was not an obstacle to the appearance of a large number of Neolithic villages. On the contrary, the frequent floods and marshy lakes provided more resources used for subsistence, architecture and communication. Consequently, many tells were established in the initial Neolithic phases and many continued in use at later stages and even in the Chalcolithic and Bronze Age (Simoska, Sanev 
1976). They were mainly concentrated around marshy areas and next to riverbanks, so a pattern of tells distribution in Pelagonia is identifiable. There are discussions on the density and absence of tells in particular regions. For the Thessalian tells, it is proposed that farming communities living there intentionally avoided particular areas or these were used as buffer zones (Perlès 1999; Runnels et al. 2009). In Pelagonia, such avoidance could be due to marshy areas, as partly documented by geographic research (Naumov, Stojkoski 2015), or could be the result of using these areas for raising crops. Consequently, the majority of tells tend to be densely clustered close to marshy lakes and riverbanks, i.e. near the most fertile soil.

There are larger tells, which were probably economic centers, and few smaller ones were erected in their vicinity at the same time, but some were established later. The question remains as to whether the later tells were founded by the same communities living on neighbouring tells or settled by newcomers. There are cases, such as Çatalhöyük in Anatolia, where the community from the East Mound in the Late Neolithic established the West Mound, which was continuously occupied in the Chalcolithic (Biehl et al. 2012). The Pelagonian tells at Trn and Slavej could have the same site history, as they both have very closely positioned tells with phases of the Early and Late Neolithic accordingly (Simoska, Sanev 1977; Naumov et al. in print). Future detailed research will determine whether there the material culture was shared with neighbouring tells and thus elaborate resettlement from one place to another.

Another question is why life on one tell was interrupted and did not continue on the same tell, but the same or different community later established a new tell, in some cases only a few metres from the earlier one. The height and general occupation area of tells is not that great, especially compared to those in Anatolia and Near East, so capacity was not an obstacle to the continuation of life in the same settlement. Some Neolithic tells were even reoccupied in the Bronze Age, such as those at Karamani and Radobor (Simoska et al. 1977; Todorović et al. 1987). Thus a reduction in resources or climate changes could be a further reason for tells to be abandoned and for the later establishment of new ones nearby. The space in the central area of tells was not used to expand the site, such as in the Great Hungarian Plain or at Sesklo in Thessaly, which were parts of larger horizontally extended settlements (Kotsakis 2006; Parkinson, Gyucha 2012). The vertical exten- sion of the settlement was common at tells in Pelagonia, although there are exceptions, such as the site at Slavej, where there no buildings were above or below the house level at the very centre of the site (Naumov et al. in print).

The reuse of a central place for occupation resulted in the rebuilding of new houses on existing ones, which further affected the creation of an artificial mound. This process was not only social, i.e. with a concentration of elites at the very centre, but was also a symbolic manifestation of a continued relationship with previous occupants. In the Balkans, this tradition began in Thessaly, as reflected not only in architecture, but also in material culture and burial rituals (Kotsakis 1999). The deceased were buried below houses which were later reoccupied or rebuilt and house models were also produced in order to maintain a link with ancestors, relatives, or those who built the first houses. Although no burials have been found inside Pelagonian settlements, the occupants produced a large quantity of house models, especially those with human representations (Fig. 7). Such anthropomorphic models are powerful representations for the identification of dwellings with particular individuals and the human body in general (Naumov 2013). In this sense, the rebuilding of houses and massive production of models indicate strong liaison between several generations within these agricultural communities and the accentuation of dwellings as focal points for the establishment of lineages.

According to the proposed dates, most Early Neolithic tells in Pelagonia were constituted around 6000 $\mathrm{BC}$, probably as a Thessalanian tradition, i.e. at the beginning of the Middle Neolithic in Thessaly (Fig. 4). Therefore, such transposition of practices and traditions is not surprising, although it is not frequent or common in other regions in the Republic of Macedonia. These habitual and symbolic traditions were further modified and localised throughout novel building techniques, spatial organisation and the production of more advanced house models, i.e. identified with the human body. This was also manifested in other spheres of material culture such as pottery, stamps, figurines, 'altars', ornaments, etc. This localised production of the Neolithic 'inventory' was synchronic with the initiation and further development of novel identities evident in pottery decoration, figurine details, stamp patterns, house models, features, etc. (Naumov 2010; 2015a). It was reflected in the understanding of the landscape, settlements and inhabitants as particular groups that 
are differentiated from others in surrounding regions. In such a vibrant isolated environment encircled by mountains, the numerous tells in the flatlands had a significant role in the establishment of social and symbolic relationship with human made and natural features of Pelagonia. This is evident both within tells themselves and their spatial organisation in the valley and thus can be further explored by means of advanced archaeological methods and more thorough research.

\section{References}

Arsovski M. 1997. Tectonic of Macedonia. Faculty of Geology and Mining. Štip.

Bailey D. 2005. Prehistoric Figurines: Representation and corporeality in the Neolithic. Routledge. London.

Benac A. 1979. Prelazna zona. In A. Benac (ed.), Praistorija jugoslavenskih zemalja II - Neolitsko doba. Akademija nauka i umjetnosti Bosne i Hercegovine. Centar za balkanološka istraživanja. Sarajevo: 363-472.

1989. Neki problemi odnosa Makedonije i Zapadnog Balkana u neolitskom dobu. Macedoniae Acta Archaeologica 10: 9-24.

Biehl P., Franz I., Ostaptchouk S., Orton D., Rogasch J. and Rosenstock E. 2012. One Community and Two Tells: The Phenomenon of Relocating Tell Settlements at the Turn of the $7^{\text {th }}$ and $6^{\text {th }}$ Millennia in Central Anatolia. In R. Hofmann, F. K. Moetz and J. Müller (eds.), Tells: Social and Environmental Space. Rudolf Habelt GMBH. Bonn: 53-65.

Bradley R. 2005. Ritual and Domestic Life in Prehistoric Europe. Routledge. London.

Budja M. 2003. Seals, Contracts and Tokens in the Balkans Early Neolithic. Documenta Praehistorica 30: 115-130.

Bunguri A. 2014. Different models for the Neolithization of Albania. Documenta Praehistorica 41: 79-94.

Chausidis N. 2003. Dualistički sliki. List. Skopje.

2007. Ženata kako personifikacija na prostorot za živeenje (od neolitot do sovremeniot folklor). In J. Lužina (ed.), Makedonskiot teatar vo kontekst na Balkanskata teatarska sfera. Fakultet za dramski umetnosti. Skopje: $45-101$.

2009. Balkanske 'kućarice' i neolitski keramički žrtvenici u obliku kuće. In S. Petrović (ed.), Etnokulturološki zbornik XIII. Svrljig: 53-72.

Chrysostomou P., Jagoulis T. and Mäder A. 2015. The 'Culture of Four Lakes': Prehistoric lakeside settlements ( $6^{\text {th }}$ $2^{\text {nd }}$ millennium $\mathrm{BC}$ ) in the Amindeon Basin, Western Macedonia, Greece. Archäeologie Schweiz 38(3): 24-32.
Fewkes V., Goldman H. and Enrich R. W. 1933. Preliminary report on an archaeological reconnaissance in Yugoslavia. Bulletin of the American School of Prehistoric Research 9: 17-32.

Fidanoski Lj. 2009. Pottery Production. In G. Naumov, Lj. Fidanoski, I. Tolevski and A. Ivkovska, Neolithic Communities in the Republic of Macedonia. Dante. Skopje: 6580.

Demoule J.-P., Perlès C. 1993. The Greek Neolithic: a new review. Journal of World Prehistory 7: 355-416.

Dumurdzanov N., Serafimovski T. and Burchfiel B. C. 2004. Evolution of Neogene-Pleistocene Basins of Macedonia. Digital Map and Chart Series 1 (Accompanying notes). Geological Society of America. Boulder.

Galović R.1964. Neue Funde der Starcevo-Kultur in Mittelserbien und Makedonien. Bericht der Romisch-Germanischen Kommision 43-44 (1962-1963). Walter De Gruyter \& Co. Berlin.

Garašanin M. 1979. Centralnobalkanska zona. In A. Benac (ed.), Praistorija Jugoslavenskih Zemalja II - Neolitsko doba. Akademija nauka i umjetnosti Bosne i Hercegovine. Centar za balkanološka istraživanja. Sarajevo: 79-212.

Gimbutas M. 1989. The Language of the Goddess. Thames and Hudson. London.

Grbić M., Mačkić P., Nadj Š., Simoska D. and Stalio B. 1960. Porodin: kasno-neolitsko naselje na Tumbi kod Bitolja. Narodni muzej Bitolj i Arheološki institut Beograd. Bitolj.

Harding A., Sievers S and Venclova N. 2006. Enclosing the Past: Inside and Outside in Prehistory. J. R. Collis Publications. Sheffield.

Hodder I. 1990. The Domestication of Europe - Structure and Cognistency in Neolithic Societes. Basil Blackwell Ltd. Oxford.

Hofmann R., Moetz F. K. and Müller J. 2012. Tells: Social and Environmental Space. Rudolf Habelt GMBH. Bonn.

Heurtley W. A. 1939. Prehistoric Macedonia: An archaeological reconnaissance of Greek Macedonia (West of 
the Struma) in the Neolithic, Bronze and Early Iron Ages. Cambridge University Press. Cambridge.

Joyce R. A. 2000. Gender and Power in Prehispanic Mesoamerica. University of Texas Press. Austin.

Karamitrou Mentessidi G., Efstratiou N., Kaczanowska M. and Kozlowski J. K. 2013. Early Neolithic Settlement of Mavropigi in Western Greek Macedonia. Eurasian Prehistory 12(1-2): 47-116.

Kitanoski B. 1977. Neolitskata naselba Čuka kaj selo Topolčani. Macedoniae Acta Archaeologica 3: 27-42.

1989. Vrbjanska Čuka. Arheološki Pregled 28: 47-48.

Kitanoski B., Simoska D. and Todorović J. 1980. Naselbata Pešterica i problemot na raniot neolit vo Pelagonija. Macedoniae Acta Archaeologica 6: 9-20.

Kitanoski B., Simoska D. and Jovanović B. 1990. Der kultplatz auf der fundstatte Vrbjanska Cuka bei Prilep. In D. Srejović, Tasić N. (eds.), Vinča and its World. International Symposium The Danubian Region from 6000-3000 BC. Serbian Academy of Science and Arts, Centre for Archaeological Research, Faculty of Philosophy. Bigz. Beograd: 107-112.

Kolištrkoska-Nasteva I. 2005. Praistoriskite dami od Makedonija. Muzej na Makedonija. Skopje.

Kotsakis K. 1999. What Tells Can Tell: Social Space and Settlement in the Greek Neolithic. In P. Halstead (ed.), Neolithic Society in Greece. Sheffield Academic Press. Sheffield: 66-76.

Kotsakis K. 2006. Settlement of Discord: Sesklo and the Emerging Household. In N. Tasić, C. Grozdanov (eds.), Homage to Milutin Garašanin. Serbian Academy of Sciences and Arts, Macedonian Academy of Sciences and Arts. Belgrade: 207-220.

Kuzman P. 1995. Podatoci za paleolitskite kulturi vo Makedonija. In G. Stardelov, C. Grozdanov and M. Mitevski (eds.), Civilizacii na počvata na Makedonija 2. Makedonska akademija na nauite i umetnostite. Skopje: 11-20.

Kuzman P. 2009. Penelope: Prehistoric Settlement. In P. Kuzman, J. Tričkovska and Z. Pavlov (eds.), Ohrid World Heritage Site. Ohrid: 22-25.

2013. Praistoriski palafitni naselbi vo Makedonija. In P. Kuzman, E. Dimitrova and J. Donev (eds.), Makedonija: mileniumski kulturno-istoriski fakti. Univerzitet Evro Balkan. Skopje: 297-430.

Kuzman P., Simoska D. and Kitanoski B. 1989. Dolno Trnovo. Arheološki pregled 1987: 38-39.
Lesure R. G. 2011. Interpreting Ancient Figurines: Context, Comparison and Prehistoric Art. Cambridge University Press. Cambridge.

Malez M. 1979. Prirodni okviri, rad na istraživanju i nalazišta paleolitskog doba u Makedoniji. In A. Benac (ed.), Praistorija jugoslavenskih zemalja I - Paleolitsko $i$ mezolitsko doba. Akademija nauka i umjetnosti Bosne i Hercegovine. Centar za balkanološka istraživanja. Sarajevo: 407-417.

Mikulčić I. 1966. Pelagonija u svetlosti arheoloskih nalaza: Od egejske seobe do Avgusta. Arheološki muzej. Skopje.

Mirčovski V., Boev B., Efremoski Z., Šorša A. and Dimov Đ. 2015. Hydrochemical Data for Ground Waters in the Bitola's Part of Pelagonia Valley, Republic of Macedonia. Geologica Macedonica 29: 15-24.

Mitkoski A. 2005. Vrbjanska Čuka kaj seloto Slavej, Prilepsko. Zbornik na Muzejot na Makedonija 2: 33-46.

Mitkoski A., Naumov G. 2007. Neolithic structure of possible ritual significance from The Republic of Macedonia. PAST 58: 8-9.

Mitrevski D. 1997. Protoistoriskite zaednici vo Makedonija. Republički zavod za zaštita na spomenicite na kulturata. Skopje.

Naumov 2009a. The process of Neolithization. In G. Naumov, Lj. Fidanoski, I. Tolevski and A. Ivkovska, Neolithic Communities in the Republic of Macedonia. Dante. Skopje: 17-27.

2009b. Patterns and Corporeality: Neolithic Visual Culture from the Republic of Macedonia. British Archaeological Reports IS 1910. Archaeopress.Oxford.

2010. Symmetry analysis of Neolithic painted pottery from Republic of Macedonia. In T. Biro-Katalin (ed.), Data Management and Mathematical Methods in Archaeology. Archaeologia e Calcolatori 21. Dipartimento Patrimonio Culturale. Roma: 255-274.

2011. Visual and conceptual dynamism of the Neolithic altars in the Republic of Macedonia. In V. Nikolov, K. Bacvarov and H. Popov (eds.), Interdisziplinäre Forschungen zum Kulturerbe auf der Balkanhalbinsel. Humboldt-Union Bulgarien. Sofia: 89-129.

2013. Embodied houses: social and symbolic agency of Neolithic architecture in the Republic of Macedonia. In D. Hoffman, J. Smyth (eds.), Tracking the Neolithic house in Europe - sedentism, architecture and practice. Springer. New York: 65-94. 
2014. Neolithic Privileges: the selection within burials and corporeality in the Balkans. European Journal of Archaeology 17(2): 184-207.

2015a. Early Neolithic Communities in the Republic of Macedonia. Archeologické Rozhledy LXVII (3): 331355.

2015b. Neolitski figurini vo Makedonija. Magor. Skopje.

2016a. Kalibrirana hronologija na neolitskite tumbi vo Pelagonija. In Lj. Fidanoski, G. Naumov (eds.), Neolitot vo Makedonija: novi soznanija i perspektivi. Centar za istražuvanje na predistorijata. Skopje: 67-96.

2016b. Prähistorische Feuchtgebiete und Phahlbauten im Ohrid-see, Republik Mazedonien. Plattform 23: 10-20.

in press. Between Wetlands and Lakes: the network of Neolithic communities in Pelagonia and Lake Ohrid, Republic of Macedonia. In K. Bacvarov, P. Gleser (eds.), Southeast Europe and Anatolia in prehistory: essays in honor of Vassil Nikolov on his $65^{\text {th }}$ anniversary. Rudolf Habelt Publishing House. Bonn.

Naumov G., Stojkoski S. 2015. Novi predistoriski tumbi vo Pelagonija. Zbornik na NU Zavod i muzej - Bitola 16: 169-185.

Naumov G., Tomaž A. 2015. The Excavation of Neolithic Tell in Mogila, Pelagonia. Patrimonium 13: 67-95.

Naumov G., Trzeciecki M., Chwiej M., Przybyła M., Bugaj M., Szczepanik P. and Podsiadło M. 2014. Arheološko, topografsko i geofizičko istražuvanje na neolitski tumbi vo Pelagonija. Patrimonium 12: 345-372.

Naumov G., Mitkoski A., Murgoski A., Beneš J., Przybiła M., Milevski Đ. and Stoimanovski I. in print. Istražuvanje na Vrbjanska Čuka kaj Slavej - 2016. Patrimonium 14.

Nikolov V. 2007. Neolitni kultovi masički. Blgarska akademija na naukite: Nacionalen arheologicheski institut i muzej. Sofija.

Özdoğan M. 1993. Vinča and Anatolia: a new look at a very old problem (or redefining Vinča Culture from the perspective of Near Eastern tradition). Anatolica 19: 173193.

2011. Archaeological evidence on westward expansion of farming communities from Eastern Anatolia to the Aegean and the Balkans. Current Anthropology 52(4): 415-430.

Parkinson W., Gyucha A. 2012. Tells in Perspective: LongTerm Patterns of Settlement Nucleation and Dispersal in Central and Southeast Europe. In R. Hofmann, F. K. Moetz and J. Müller (eds.), Tells: Social and Environmental Space. Proceedings of the International Workshop "Socio-Environmental Dynamics over the last 12,000 years: The Creation of Landscapes II (14th-18 ${ }^{\text {th }}$ March 2011)" in Kiel. Volume 3. Universitätsforschungen zur prähistorischen Archäologie Band 207. Rudolf Habelt GMBH. Bonn: 105-116.

Perlès C. 1999. The Distribution of Magoules in Eastern Thessaly. In P. Halstead (ed.), Neolithic Society in Greece. Sheffield Academic Press. Sheffield: 42-56.

2001. The Early Neolithic in Greece. The first farming communities in Europe. Cambridge University Press. Cambridge.

Puteska A., Dimovska B., šajn R. and Stafilov T. 2015. Distribution of chemical elements in soil samples from the Pelagonia region, Republic of Macedonia. Geologia Croatica 68(3): 261-272.

Reingruber A. 2011. Early Neolithic settlement patterns and exchange networks in the Aegean. Documenta Praehistorica 38: 291-305.

Rosenstock E. 2009. Tells in Südwestasien und Südosteuropa: Verbreitung, Entstehung und Definition eines Siedlungsphänomens. Urgeschichtliche Studien II. Bernhard Albert Greiner. Grunbach.

Runnels T. C., Payne C., Rifkind N., White C., Wolff N. and LeBlanc S. 2009. Warfare in Neolithic Thessaly: A Case Study. Hesperia 78(2): 165-194.

Ruzi E. 2009. Investigating compositional variability on the Early Neolithic ceramics among Korçë Region, Albania. Chronika 3: 1-15.

Sabattani S., Manfredi R. and Fiorino S. 2010. Malaria infection and anthropological evolution. Saude e Sociedade 19: 64-83.

Sanev V. 1988. Neolitskoto svetilište od "Tumba" vo Madjari. Macedoniae Acta Archaeologica 9: 9-30.

1994. Mlado kameno vreme. In D. Koco (ed.), Arheološka karta na Republika Makedonija - Tom I. Macedonian Academy of Science and Arts. Skopje: 26-42.

1995. Neolitot i neolitskite culturi vo Makedonija. In G. Stardelov, M. Matevski and C. Grozdanov (eds.), Civilizacii na poćvata na Makedonija 2. Macedonian Academy of Science and Arts. Skopje: 21-46.

2006. Anthropomorphic Cult Plastic of Anzabegovo-Vršnik Cultural Group of the Republic of Macedonia. In N. Tasić, C. Grozdanov (eds.), Homage to Milutin Garašanin. Serbian Academy of Sciences and Arts, Macedonian Academy of Sciences and Arts. Belgrade: 171-191. 
Simoska D., Kuzman P. 1990. Tumba Optičari. Arheološki Pregled 1988: 63-66.

Simoska D., Sanev V. 1975. Neolitska naselba Veluška tumba kaj Bitola. Macedoniae Acta Archaeologica 1: 2585 .

1976. Praistorija vo Centralna Pelagonija. Naroden Muzej. Bitola.

1977. Neolitska naselba na Mala Tumba kaj selo Trn, Bitola. Macedonia Acta Archaeologica 3: 215-237.

Simoska D., Kitanoski B. and Todorović J. 1977. Praistoriska naselba Tumba vo selo Karamani kaj Bitola. Macedonia Acta Archaeologica 3: 9-25.

1979. Neolitska naselba vo selo Mogila kaj Bitola. Macedonia Acta Archaeologica 5: 9-30.

Sinadinovski P. 2016. Rekognosciranje na neolitski lokaliteti vo Raečkata klisura. In Lj. Fidanoski, G. Naumov (eds.), Neolit vo Makedonija: novi soznanija i perspektivi. Centar za istražuvanje na predistorijata. Skopje: $55-$ 66.

Srdoč D., Sliepčević A., Obelić B., Horvatinčić N. and Bošković R. 1977. Radiocarbon measurements IV. Radiocarbon 19(3): 465-475.

Steadman S. R. 1995. Prehistoric interregional interaction in Anatolia and the Balkans: an overview. Bulletin of the American Schools of Oriental Research 299-300: 13-32.

Temelkoski D., Mitkoski A. 2001. Neolitski antropomorfni statuetki vo predistoriskata zbirka na Zavod i muzej Prilep. Makedonsko nasledstvo 17: 53-69.

2005. Sadova keramika od Vrbjanska Čuka. Macedoniae Acta Archaeologica 16: 29-53.

2006. Praistoriska naselba Mogila Senokos. Macedonia Acta Archaeologica 17: 55-88.
Todorova H., Vaisov I. 1993. Novo - kamennata epoha v Blgarija. Nauka i izkustvo. Sofia.

Todorović J., Simoska D. and Kitanoski B. 1987. Osvrt vrz arheološkite istražuvanja na praistorijata vo Pelagonija. Zbornik na trudovi na Zavod, Muzej $i$ Galerija Bitola 6-7-8: 5-24.

Tolevski I. 2009. Architecture. In G. Naumov, Lj. Fidanoski, I. Tolevski, I. and A. Ivkovska, Neolithic Communities in the Republic of Macedonia. Dante. Skopje: 37-44.

Trifunovski J. 1998. Bitoljsko-prilepska kotlina: antropogeografska proučavanja. Srpska akademija nauka i umetnosti. Beograd.

Valastro S., Mott Davis J. E. and Varela A. G. 1977. University of Texas at Austin: Radiocarbon dates 11. Radiocarbon 19(2): 280-325.

Van de Noort R., O'Sullivan A. 2006. Rethinking Wetland Archaeology. Duckworth. London.

Vasileva M. 2005. Kade e našeto minato? Voved kon praistorijata na Pelagonija. Visoi. Bitola.

Westphal T., Tegel W., Heußner K.-U., Lera P. and Rittershofer K.-F. 2010. Erste dendrochronologische Datierungen historicher Hölzer in Albanien. Archeologische Anzeiger 2: 75-95.

Zdravkovski D. 2006a. Kultot na Golemata Majka vo neolitot na Makedonija. Folia Archaeologica Balkanica I: 53-61.

2006b. New Aspects of the Anzabegovo-Vršnik Cultural Group. In N. Tasić, C. Grozdanov, (eds.), Homage to Milutin Garašanin. Serbian Academy of Sciences and Arts, Macedonian Academy of Sciences and Arts. Belgrade: 99-110. 